\title{
Syphilis in art: an entertainment in four parts. Part 4
}

\author{
R S Morton
}

The Nineteenth and Twentieth Centuries

Gillray and Rowlandson bridge the gap between Hogarth and the cartoonists of the 19th and 20th centuries. There is one interesting intervening step (fig 48). It is a very fine early example of a coloured stippled engraving such as might be called for and used in teaching dermatology at the time. The engraver is Fresca, circa 1806, after a painting by Moreceau Valvile. The woman's condition was diagnosed as late secondary syphilis by the fine teacher and very nosologically orientated dermatologist, Baron Alibert (1768-1837.). ${ }^{43}$ This work was exhibited at a Wellcome Institute Exhibition in 1978.4

Two other examples, one from the late 18th century and from early in the 19 th century, pointedly reveal public attitudes to venereal infections. ${ }^{45}$ The first is called Traps of the World (fig 49). Its author, Ganière, symbolises life by three large basket traps representing Brawling, The Tavern and The Brothel. At each a well dressed entrepreneur calls for clients and invites them to enter his basket. Those entering any basket are thereupon automatically declared eligible for admission to hospital by the back door. The snatches of poetry which we have seen to be a regular feature since Ulsenius, are here for the benefit of those resistant to the sales talk but who are confidently believed by the operators to be potential exhibitors of medico-social pathology.

The second French engraving was published by Martinet in 1816 (fig 50). It first appeared in Paris during the occupation of that city by the victorious troops after the battle of Waterloo, that is, in the summer of 1815. The cartoon pours scorn on the officers of the Allied Armies. The doctor presents the officers with medicines on the occasion of their demobilisation; some purport to be cures for gonorrhoea. For syphilis, he offers poultices, opiates and mercury pills.

One unusual minor art form surfaced in mid-19th century England. Joseph Towne, son of a dissenting parson, was born at Royston, Hertfordshire, in 1808 . Early in his life he showed a talent for modelling clay. He secretly modelled a complete skeleton and took it to Guy's Hospital where the notable surgeon, Astley

Sub-Department of Medical History, University of Sheffield, UK

R S Morton
Cooper, was so impressed and delighted that the boy was offered a job. Until his death in 1879, Joseph Towne made several hundred, life size, coloured wax models. His work encompassed anatomical, pathological and dermatological subjects. He conducted his moulage making behind locked doors and the secrets of his techniques, for example the dyes he employed and how he used them so effectively, died with him.

The loving and restorative care and attention long given to Towne's moulages by staff at Guy's Hospital has recently been generously supported by grants from the Dunhill Trust and other sources. The refurbished moulages now help to form a fine, modern exhibition and high quality teaching facility. Two examples of Towne's work have been selected to demonstrate infectious acquired and congenital syphilis (figs $51 \& 52$ ). In the flesh, as it were, the skin appearance is most realistic and the coppery-redness of the rash true to life.

The unmentionableness of the venereal diseases in Victorian times reached its apogee when a Bill to

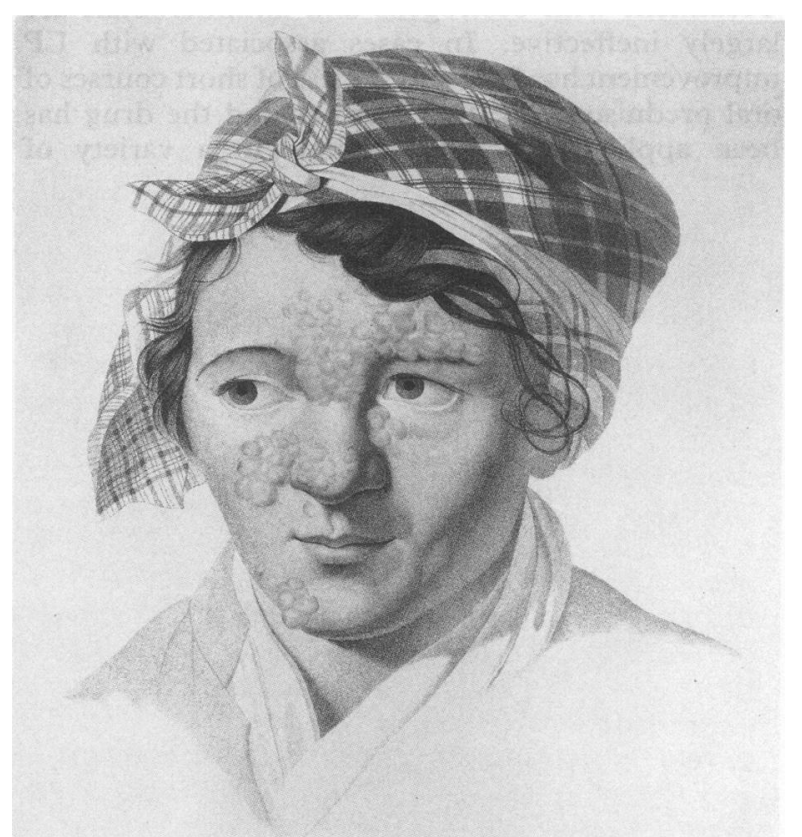

Fig 48 Fresca. Stippled and coloured engraving after $G$. Moreau Valvile. c. 1806. Syphilide pustuleuse en grappe. Possibly for Baron J. L. M. Alibert, Clinique de l'hopital Saint-Louis, Paris. Cormon, 1833 pl. 45. Courtesy Wellcome Institute Library. 


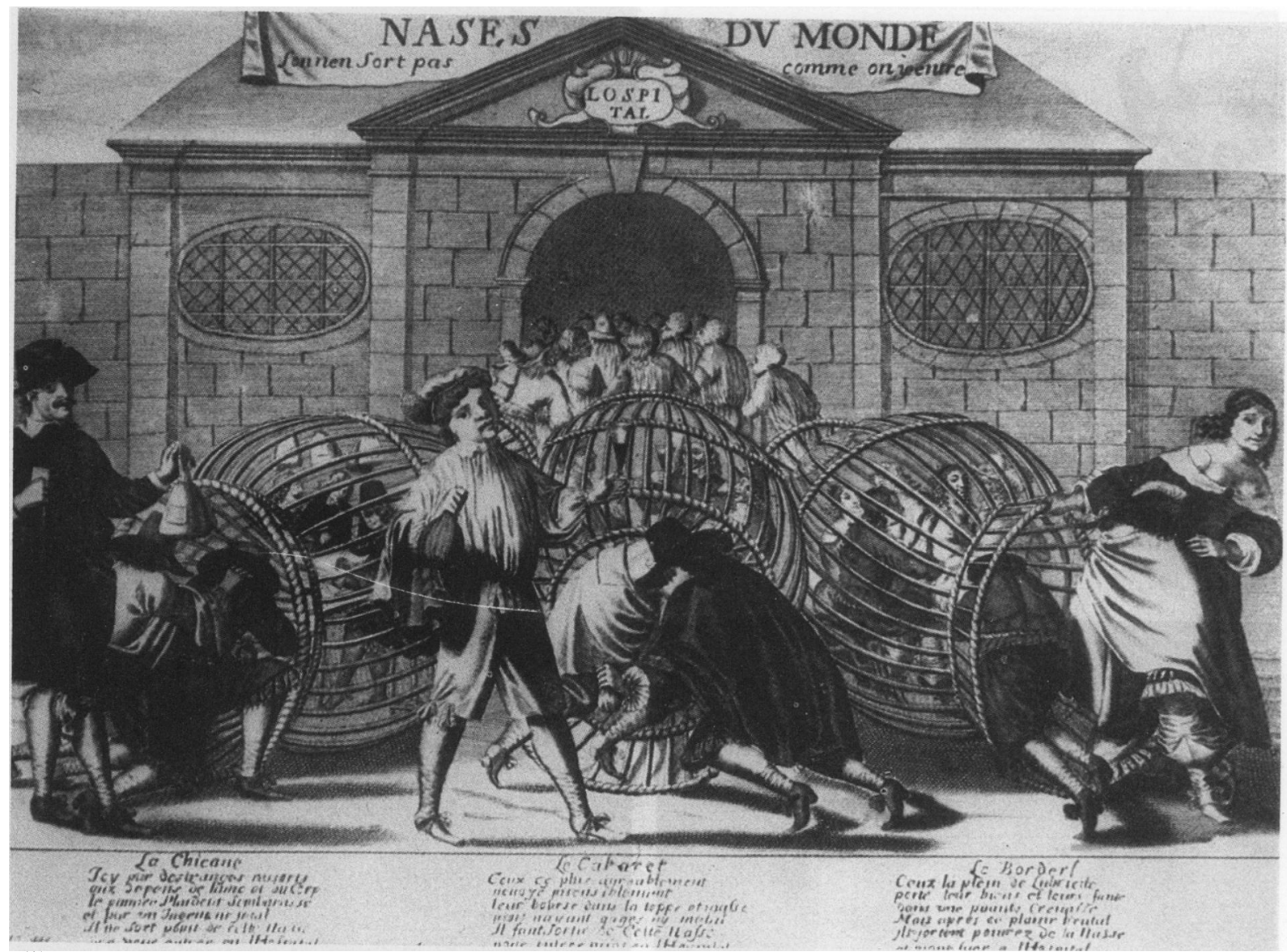

Fig 49 Ganière. Les Trois Nasses du Monde (The Traps of the World). Engraving c. 1790. Courtesy Société des Gens de Lettres de France, Paris.

control these infections was named, in 1864, the Contagious Diseases Act. It was an example of how the moral strictures of the time were supported by legislation. The law was enacted because of excessively high infection rates in soldiers and sailors in home stations. The Act aimed at prevention. It provided for the arrest, compulsory examination and detention of women suspected of spreading syphilis and gonorrhoea. Liberal minded people reacted powerfully. Mrs Josephine Butler (1828-1906) headed the "Abolitionists". The law, they declared, denied women their constitutional right of freedom of action and should be abolished. They pursued their objectives relentlessly and after a period of suspension the Act was repealed in $1886 .{ }^{46}$ The fight to replace the concept of VD Control by regulation and detention with something more civilised and more effective was also under way in other parts of Europe and nowhere was it more ardently pursued than in Norway.

Christian Krohg (1852-1925) was a Norwegian writer and painter with a strong social conscience. He used his talents to raise awareness in others especially about ill-paid young women. ${ }^{47}$ His novel Albertine characterised in detail the lot of the contemporary prostitute. Norway, no less straight-laced than England, was outraged by this public display of a taboo subject and the book was banned the day after publication. With the inevitability of Newton's third law of motion, this action prompted an equal and opposite reaction. The cause of women was overtly and fiercely championed. Krohg, after several trial studies, produced in 1887 a painting, $3 \times 2$ metres, depicting a scene from his book (fig 53). It shows Albertine being escorted by a policeman into the doctor's surgery where she is to be compulsorily examined for venereal disease. Krohg's public display of this outrageous invasion of a woman's body, combined as it was with a taboo subject, caused a sensation and the humiliating practice ceased.

Several versions of Christian Krohg's painting exist. A 1917 version shows how the artist has developed. For example, he uses a fully loaded brush with aplomb and introduces adroitly sited highlights with dramatic effect. This production is thought by some to show greater awareness of the tensions 


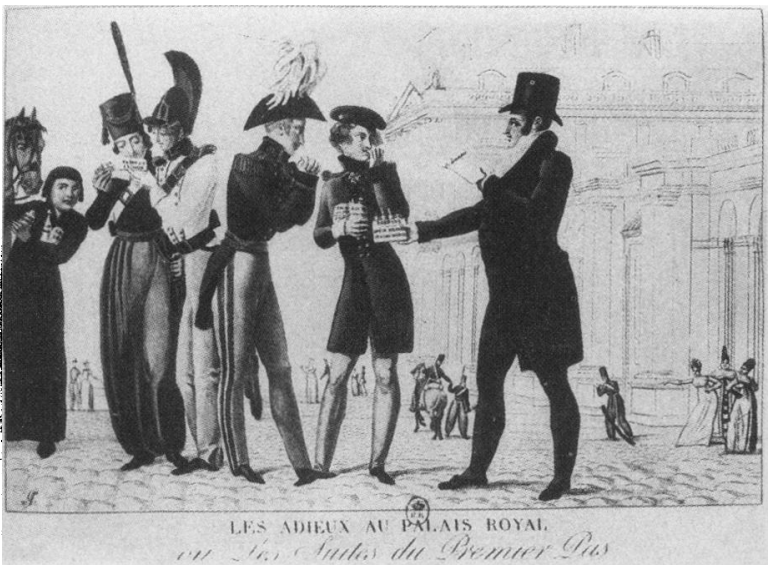

Fig 50 Martinet. Les Adieux au Palais Royal. (Goodbyes to Palais Royal.) Engraving 1816. Courtesy Société des Gens de Lettres de France, Paris.

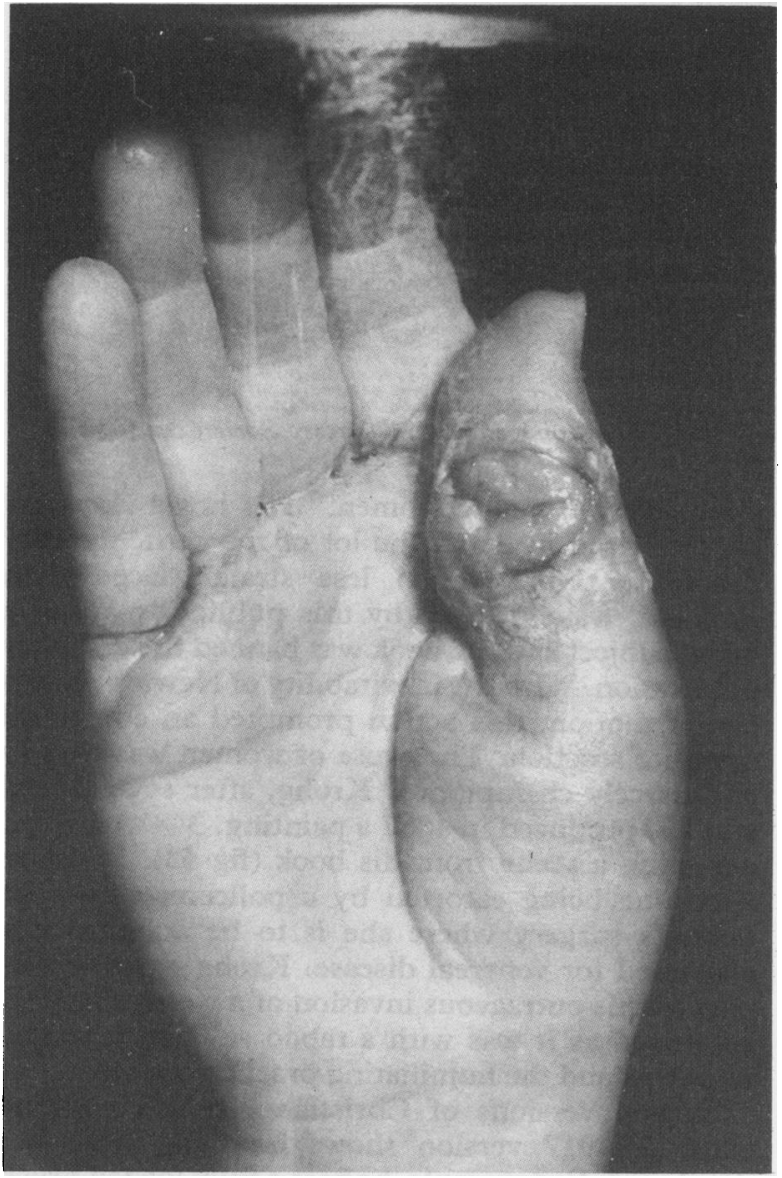

Fig 51 Joseph Towne. Primary and Secondary Syphilis. Moulage, mid-19th century. Courtesy of The Dean, United Medical and Dental Schools of Guy's and St. Thomas's Hospitals, London.

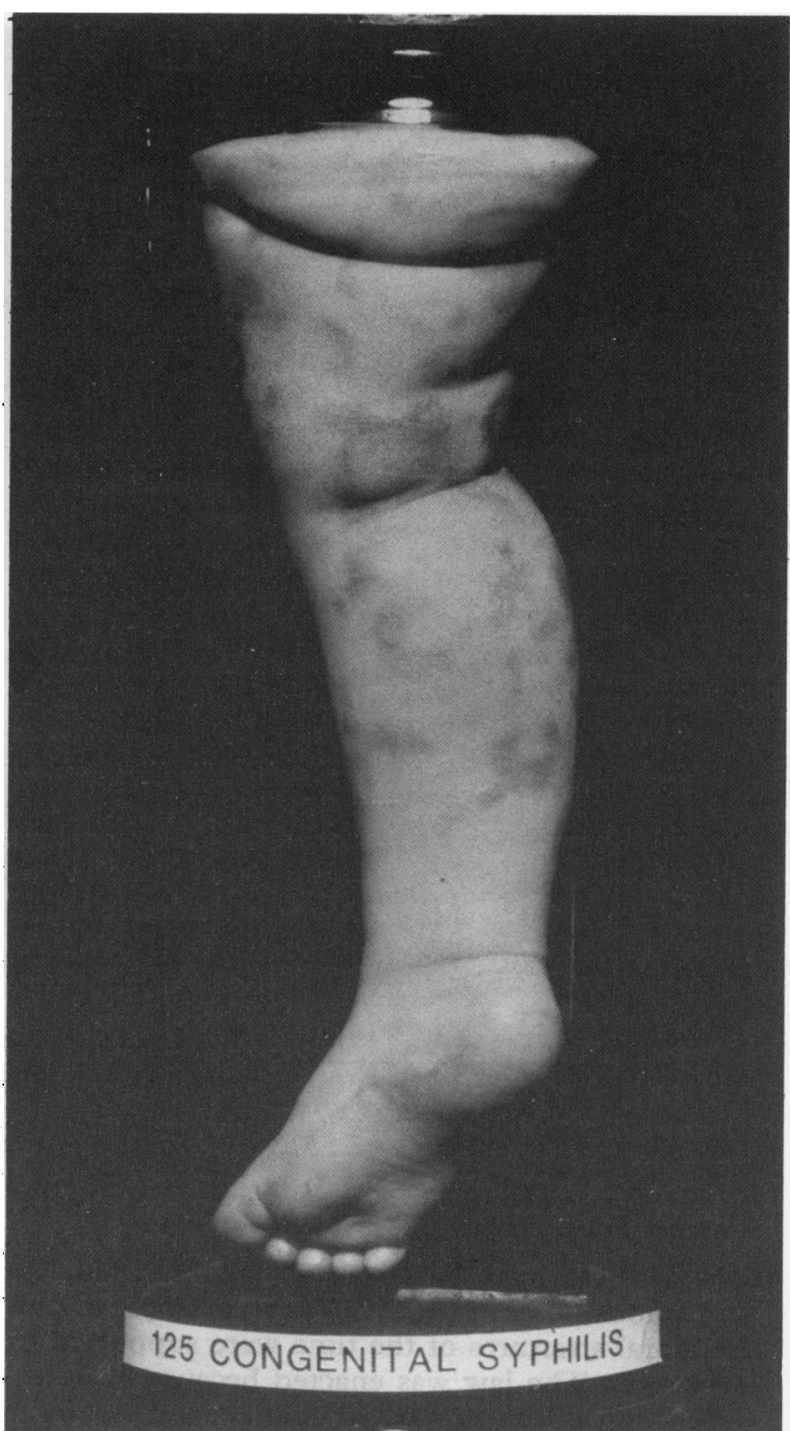

Fig 52 Joseph Towne. Infectious congenital syphilis. Moulage, mid-19th century. Courtesy of The Dean, United Medical and Dental Schools of Guy's and St. Thomas's Hospitals, London.

between the characters, the involvement of each and the misery endured by all Albertines. My personal preference, however, is for the 1887 painting. Like much of his earlier work it has a subtle photographic quality which gives it the instantaneous impact of stark reality. There is no escaping the tension Krohg engenders.

Meanwhile in Paris, uncomprehending Frenchmen, with confirming sang froid, were taking their wives and families to visit the local brothels on Sunday afternoons. Something of this open and objective attitude to one of life's less attractive aspects is reflected in the city's art. 


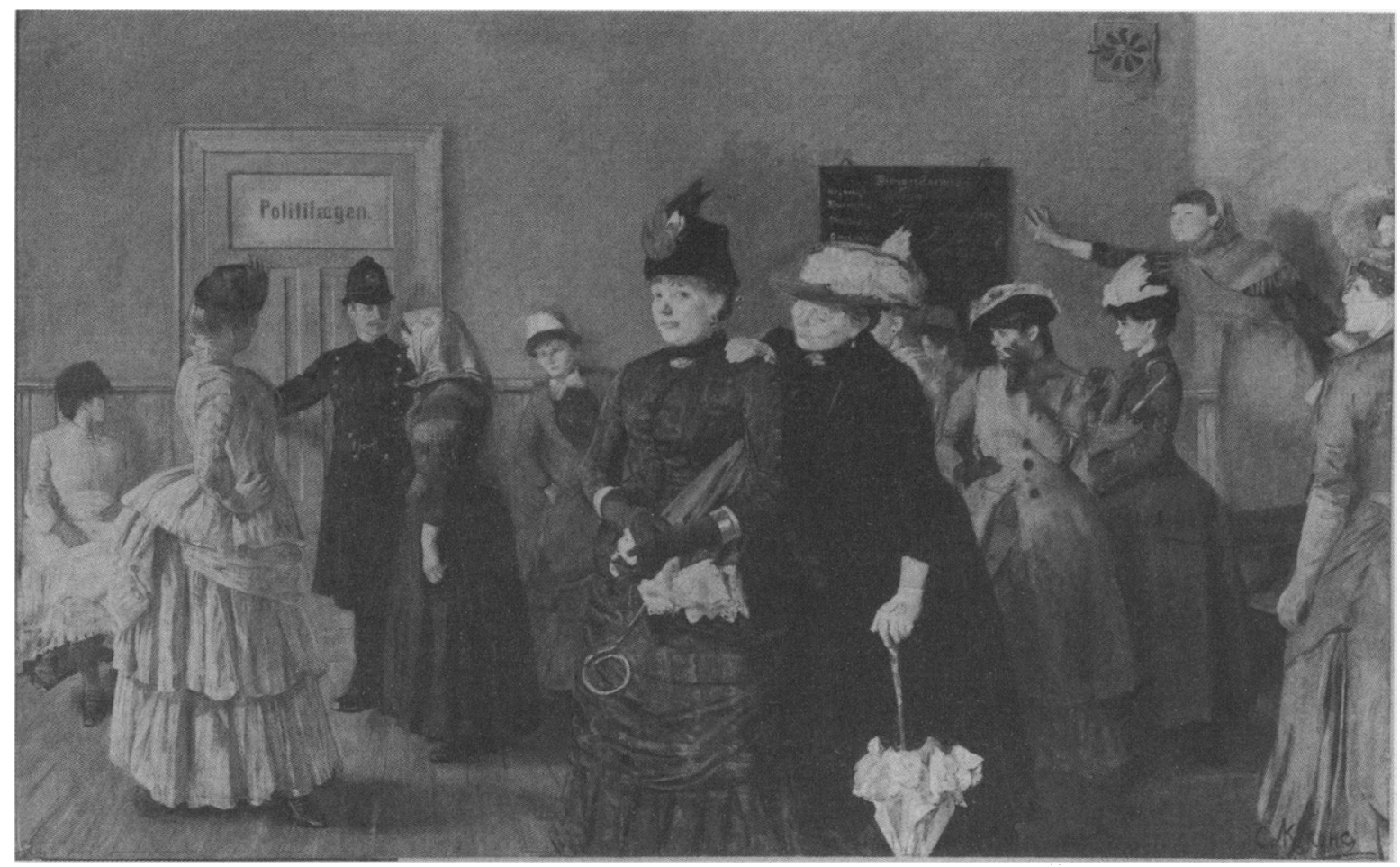

Fig 53 Christian Krohg. Albertine, 1886-87. Oil on canvas $211 \times 326 \mathrm{cms}$. Courtesy Nasjonalgalleriet, Oslo.

In his decline into debauchery, Toulouse-Lautrec (1864-1901) frequented Paris's demi-monde of bars, cafés and music halls with their ambience of abandonment to forced and false physical expressions of gaiety. ${ }^{48}$ These features contrast markedly with the sense of resignation and forlorn hope expressed in the relaxed stance and aura of weary movement of Toulouse-Lautrec's off-duty women as he met and painted them in the brothels. His representations of them evoke more than sympathy although the artist is clearly at one with them. One senses that he is privy to the tragic, even groteseque, life story behind each painted face. It is dramatic simpatico rather than syrupy simpatia. Nowhere is this better displayed than in the artist's 1894 production Medical Inspection at the Rue des Moulins (fig 54). The nameless women file sadly past a faceless doctor in an orderly line. Their air is one of hopeless disinterest and weary resignation. Of all brothel scenes it must be the most fearsome. Clearly, Toulouse-Lautrec could be audacious, not only technically but in his social comment.

Figure 55, An Examination at the Faculty of Medicine was completed by Toulouse-Lautrec shortly before his death in 1901. Durel has recorded many interesting facets on the work. ${ }^{49}$ The candidate is the artist's cousin and confidant, Gabriel Tapie de Céleyran, who did in fact present himself for the oral part of his thesis examination in 1899. Such occasions called for four adjudicators. On this apochryphal occasion, two are recognisable. On the right is Professor Robert Wurtz, founder of the Medical School, who was a bacteriologist and hygienist. But it is the central character who is of special interest to us. After the kind of thoroughly detailed research for which he has long been renowned, Durel leaves us in no doubt that it is none other than the renowned syphilogist, Alfred Fournier (1832-1914). The square head and the moustache overhanging a small mouth are telling features.

Those of us who have in our time been candidates and examiners at professional examinations will no doubt agree that Toulouse-Lautrec's use of colours - the harmonies of greens and blacks with the violent red-reminds us unmistakably of the atmosphere associated with a viva voce.

Durel reminds us also that in 1946 and 1947 a postage stamp was produced in France using a likeness of Fournier. The tax from the sale of this modern minor art form served to finance the campaigning of La Ligue Nationale Française contre le Péril Vénérien.

Some artists' social comments are frankly brutai and our next is one such. Félicien Rops (1833-98), a Belgian of Hungarian ancestry, was left and squandered a fortune in his youth. He was a self-taught, 


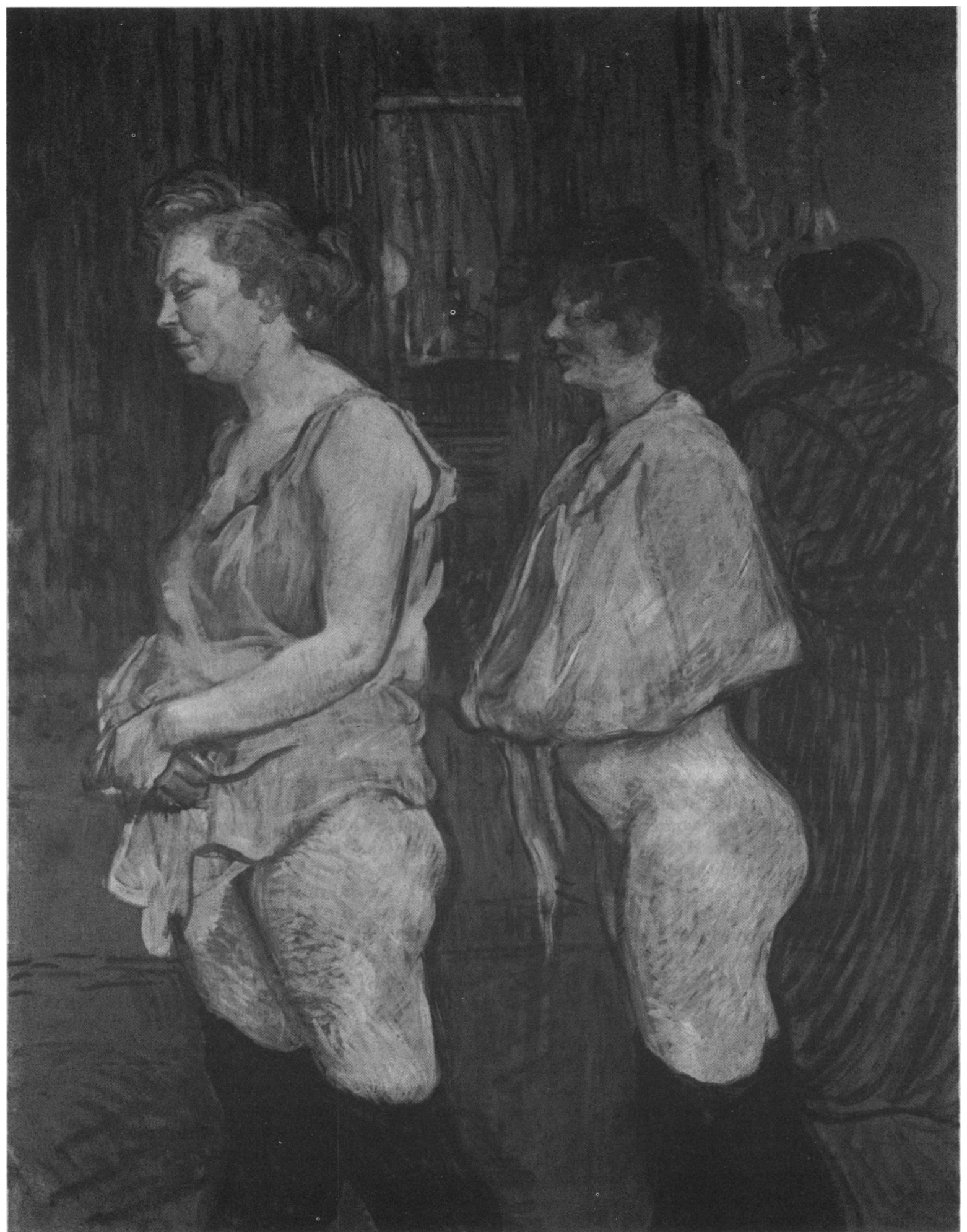

Fig 54 Henri de Toulouse-Lautrec. Rue des Moulins. Oil on cardboard, mounted on wood, $83 \times 61 \mathrm{~cm} .1894$. Courtesy Chester Dale Collection. National Gallery of Art, Washington DC. 


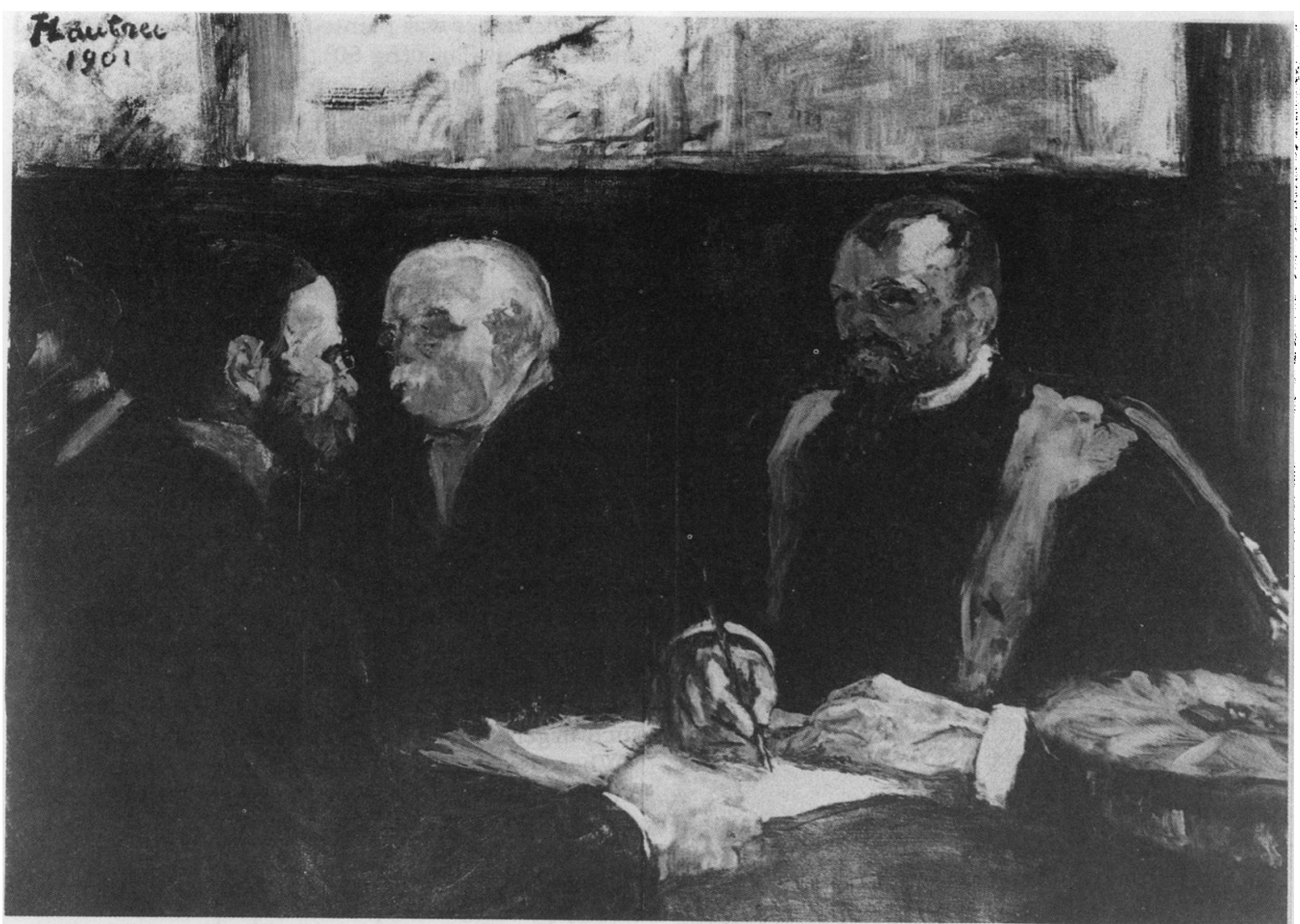

Fig 55 Henri de Toulouse-Lautrec. Examen à la Faculté de Médicine. Oil on canvas. $65 \times 81$ cm. 1901. Courtesy Musée Toulouse-Lautrec, Albi.

cynical caricaturist who published much of his work in the politico-satirical journal Uglenspiegl. His marvellously accurate draughtsmanship and brilliant technique was constantly threatened with ruin by the pornographically offensive nature of his most biting cynicism. Thus many thought Rops more infamous than famous. Figure 56 was found in a museum dedicated to him in his home town of Namur in central Belgium. It leaves one in no doubt that he considered women wicked, and a source of evil and deadly disease.

What Félicien Rops said à la fin de $19^{\mathrm{e}}$ siècle, George Grosz (1893-1959) reiterated in the years on both sides of World War I. Grosz was a Dadaist ("dada" is Slavonic for "yes", "yes"-to life)..5 Robert Hughes in his recent television series characterised him as a "master of radical sourness". ${ }^{51}$ Grosz saw no good anywhere in his early days. He mellowed with age and was honest enough to call his 1946 autobiography, in German, "A little 'Yes' and a big "No"'. In the first quarter of the 20th century, Grosz saw corruption all around him and found it frequently associated with greed and wicked militarism. Evil of all kinds stalked the bars, the brothels and the battlefields. He drew prostitutes as harbingers of degradation and disease (fig 58). While none of his work has been found to specify syphilis, his harsh social comments are certainly germane to the prevalence of venereal diseases at the time; between $10 \%$ and $12 \%$ of big city dwellers in Europe had positive blood tests for syphilis. Whether Grosz's endeavours did anything to prompt women to assert themselves or reformers to liberalise attitudes to venereal disease in Europe and America, where his work circulated widely, is a matter for speculation. Grosz's work is often exquisitely, even gently, executed and then in a way more brilliantly expresses his fiercely vindictive hatred of man's, and woman's inhumanity to man.

There were of course other schools of thought in the art world. One of the prolific contenders for leadership of the 19th century's young Expressionist movement was the Norwegian artist, Eduard Munch (1863-1944). His work, like that of other Expressionists such as van Gogh, Gauguin and Klee, reflects his philosphy of life. He spent his formative years in Paris and Berlin. He was tall and thin and introspective. He was much pre-occupied with love, personal 


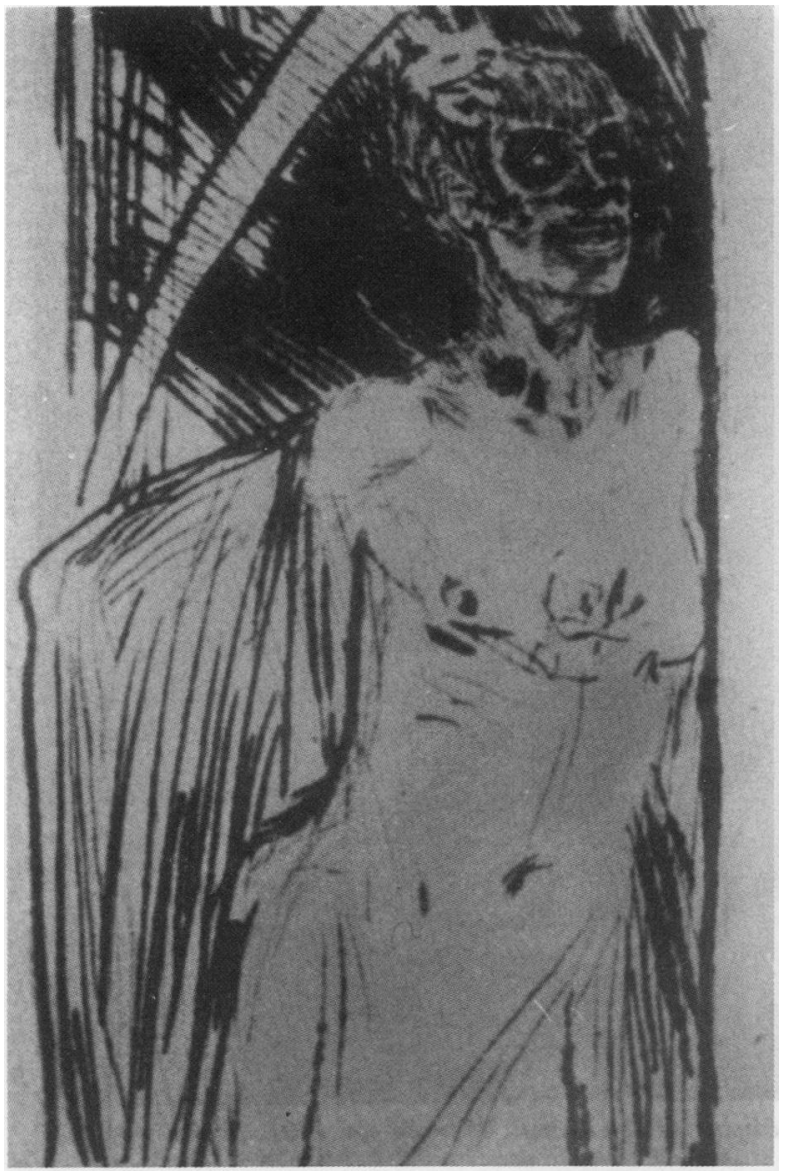

Fig 56 Félicien Rops. Mors Syphilitica. Dry point drawing $24.6 \times 17 \cdot 7 \mathrm{~cm}$. Courtesy Musée Rops, Namur.

tragedy and death of loved ones. Even a short time spent browsing through a book of his (in colour) paintings $^{52}$ gives one a flavour of the kind of experience familiar to doctors who listen to, and hear, the illogical distortions of neurotic patients. Munch is little concerned with emphasis on artistic form, perspective, harmonies or colours. His concern is with winning the viewer to an appreciation of what he feels and what he feels with the intense conviction of the chronic hysteric.

Munch was a close friend of the Swedish dramatist, Strindberg, and he knew well his fellow-Norwegian, Ibsen. Among several pieces concerning syphilis, Munch provided a series of stage sketches to illustrate Ibsen's play Ghosts. Most telling of the series is an oil sketch of the play's final scene (fig 59). It is generally called Osvald's Breakdown and shows the near blind and demented congenitally infected son frantically appealing to his distraught parent, "Show me the sun, mother".

But there is much more to Munch. His Heritage or
The Inheritance was painted in 1897 when he was 34 and living in Paris (fig 60). It shows a tearful young mother with her puny, syphilitic infant on her lap. She sits in the doctor's waiting room alone. The public received the work with a mixture of amusement and indignation. Many judged it to have exceeded the limits of permissible expression. Munch first called it The Syphilitic Child. Some said he mocked the many artistic representations of the Madonna and child and that this was the cause of the violent reactions which prompted the painting's withdrawal and change of name.

At first glance one is liable to see only the old familiar Victorian story of the "fallen" and infected woman abandoned by her lover when most in need of support. The oftener and longer one looks at the work, however, the more does one find it compelling, poignant and mood provoking. The mother's face is red and contrasts with the greenish skin of the rashaffected baby. The autumn leaves on the dress seem to symbolise the imminence of death. It was 1897 and treatment of the child was very unlikely to be successful. All this, with the distortions accompanying the near absence of perspective, prompt in one such urgent questions as "Did the man warn her?"; "Where is he now?"; "Is there really no hope for the child?" "How will the doctor, so soon to be seen,

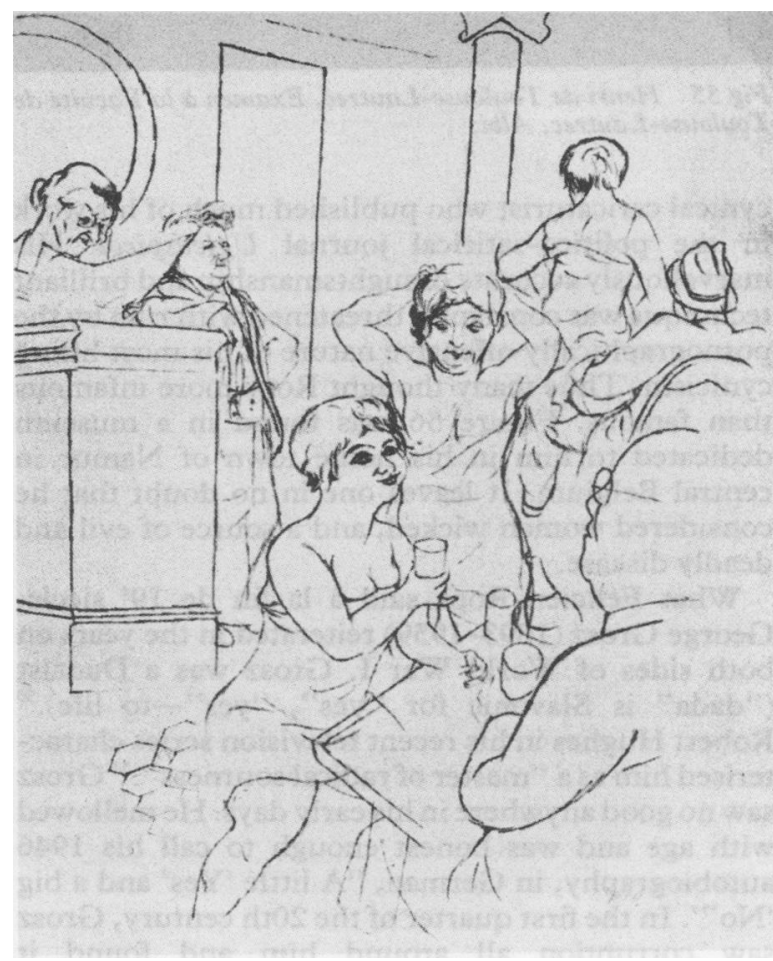

Fig 57 George Grosz. Bordello. Drawing c. 1910. Courtesy Courtauld Institute of Art, London. 
react? Will he match the young mother's anguish and insight?"; "How will this tragedy end?".

We are a long way now from the contenting, intellectualising needed for an appreciation of van Veen's Allegory of Indiscreet Youth. Here we are involved with the artist. Munch the Expressionist has engendered in us what every Expressionist painter seeks in a viewer-a feeling of "inner tension". It may be no more than a mood of helpless, tight-lipped compassion, but our arrest is complete and we know it is inescapable.
If Munch's call for compassion rather than condemnation shows him to be ahead of public sentiment, that cannot be said of our next artist. He was very much a man of his time for all of his time.

The Spaniard, Pablo Picasso (1881-1973), completed his first Cubist painting as early as the spring of 1907 . His friends thought little of it and it lay in limbo for many years. It was nearly 2.5 metres square and called Les Demoiselles d'Avignon (fig 61). The scene is a brothel parlour in Carre (street) d'Avignon in Barcelona near Picasso's student home.

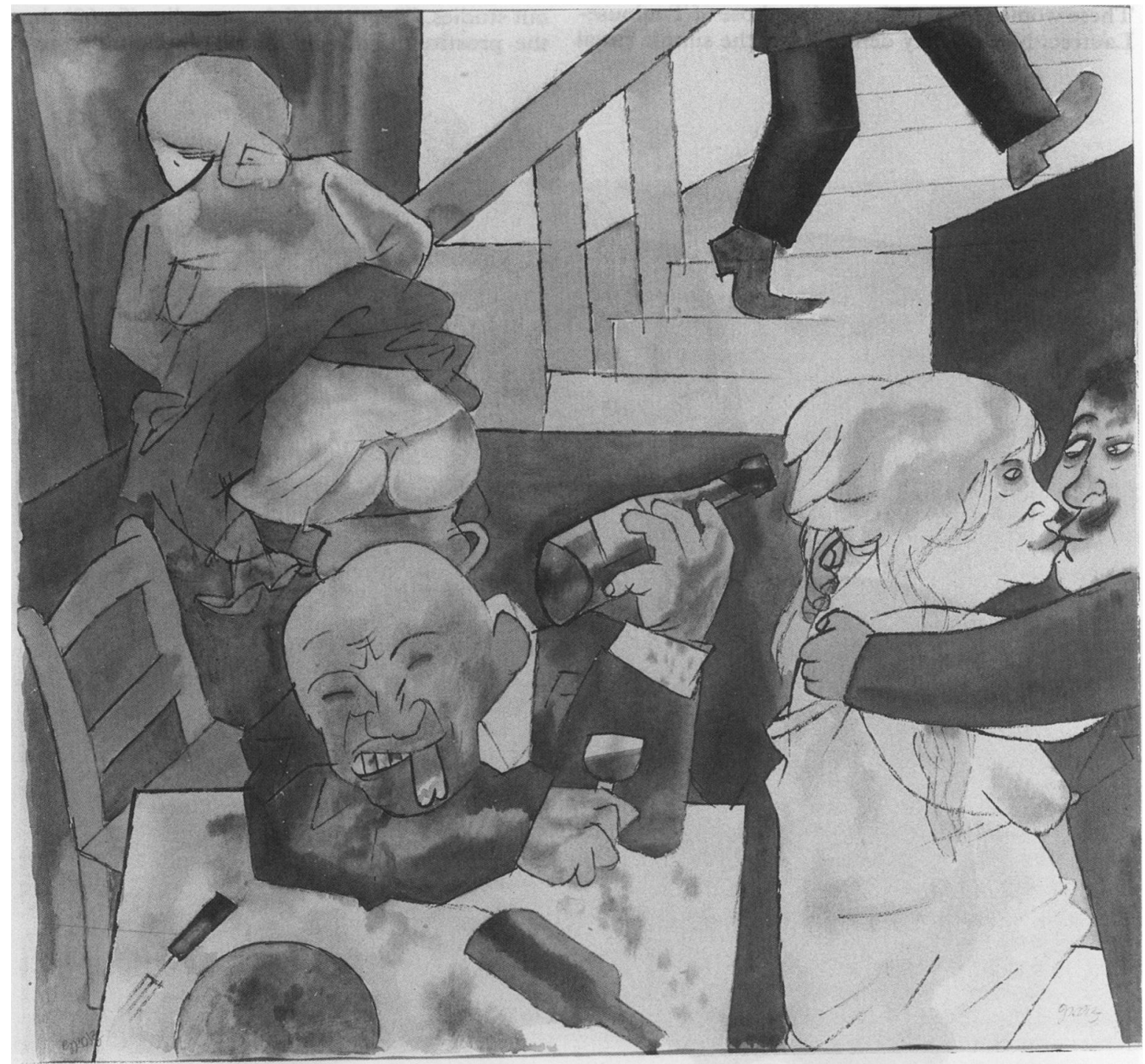

Fig 58 George Grosz. Bordello. Drawing $50 \times 50 \mathrm{~cm}$. c. 1922. Courtesy of The Design and Artists Copyright Society Ltd., London. 
What prompted this first excursion into Cubism? Rather than follow other artists into the new abstract and pretty look then in vogue, Picasso tried to revitalise the representation of reality in art by abandoning perspective and painting objects and figures from more than one angle simultaneously. In this first example (fig 61) we also find African and Pacific influences, popular at the time, and remnants of his own blue and rose periods. What is new is that his figures have straight outlines, with only angle overlappings to indicate planes. Mask-like faces are shown full face and in profile at one and the same time. But even more striking is the stance of the parading prostitutes. Note their interrogative stare. These women are not victims like those of ToulouseLautrec. Nor do they demonstrate the simple ritual dignity of Paul Gaugin's South Sea island prostitutes in his Ta Matete (The Market) of 1892. Picasso's prostitutes present themselves as women of consequence-vital, assertive and perhaps to some, even frightening. They disturb us quite differently from those of any other artist and they do it so purposely that we are conscious of their power.

Some say Picasso was afraid of women but there is much in his life story to contradict this view. Was he perhaps afraid of something more sinister?

Some clue to the truth of Picasso's thinking can be found in the trials that preceded the production of Les Demoiselles d'Avignon. Picasso made no less than seventeen preliminary sketches and three well filled out studies. The third of these studies (fig 62) shows the prostitutes grouped around a centrally seated

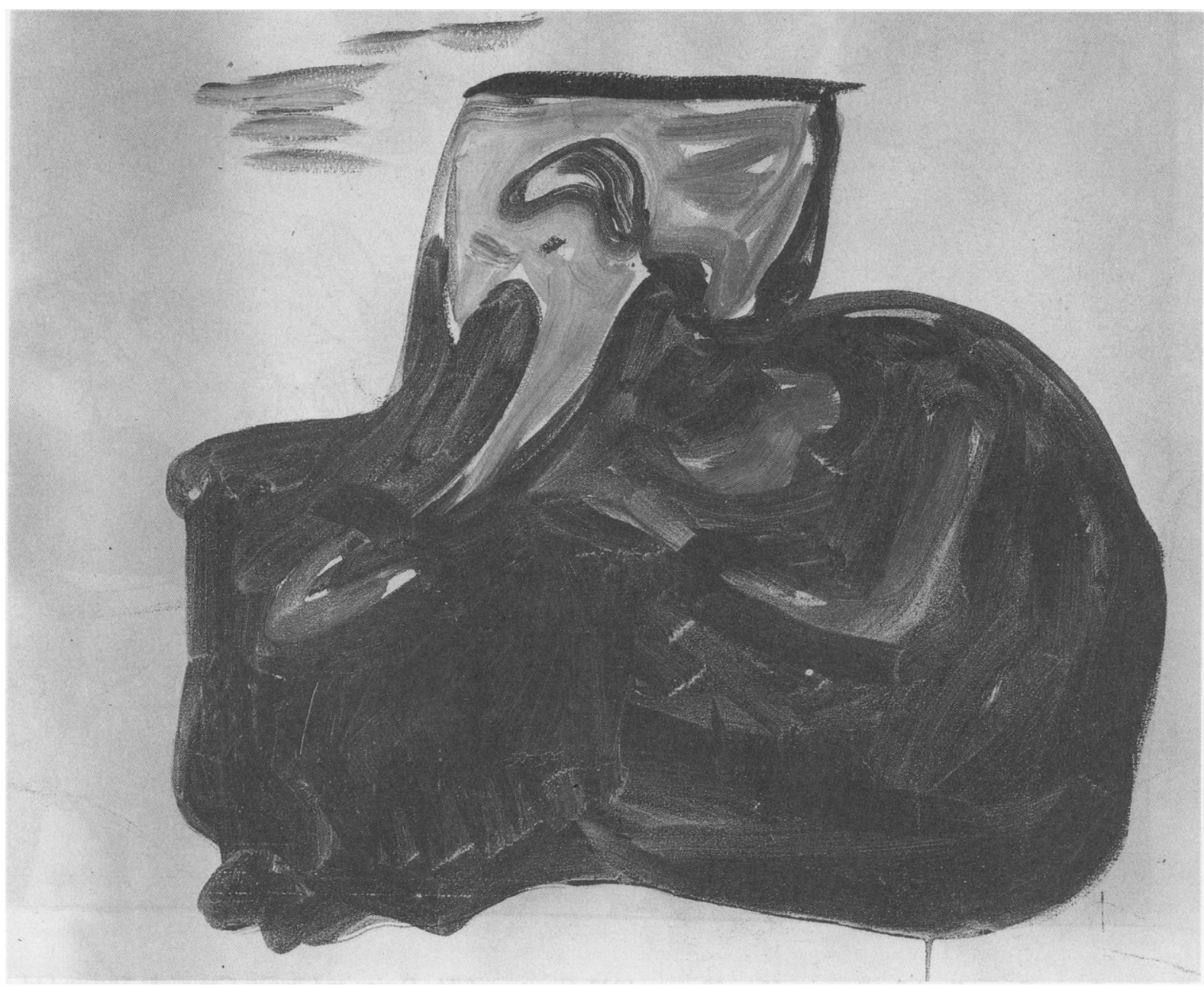

Fig 59 Eduard Munch. Osvald's Breakdown. Oil on canvas from a stage sketch. 1880. Courtesy Munch Museet, Oslo. 


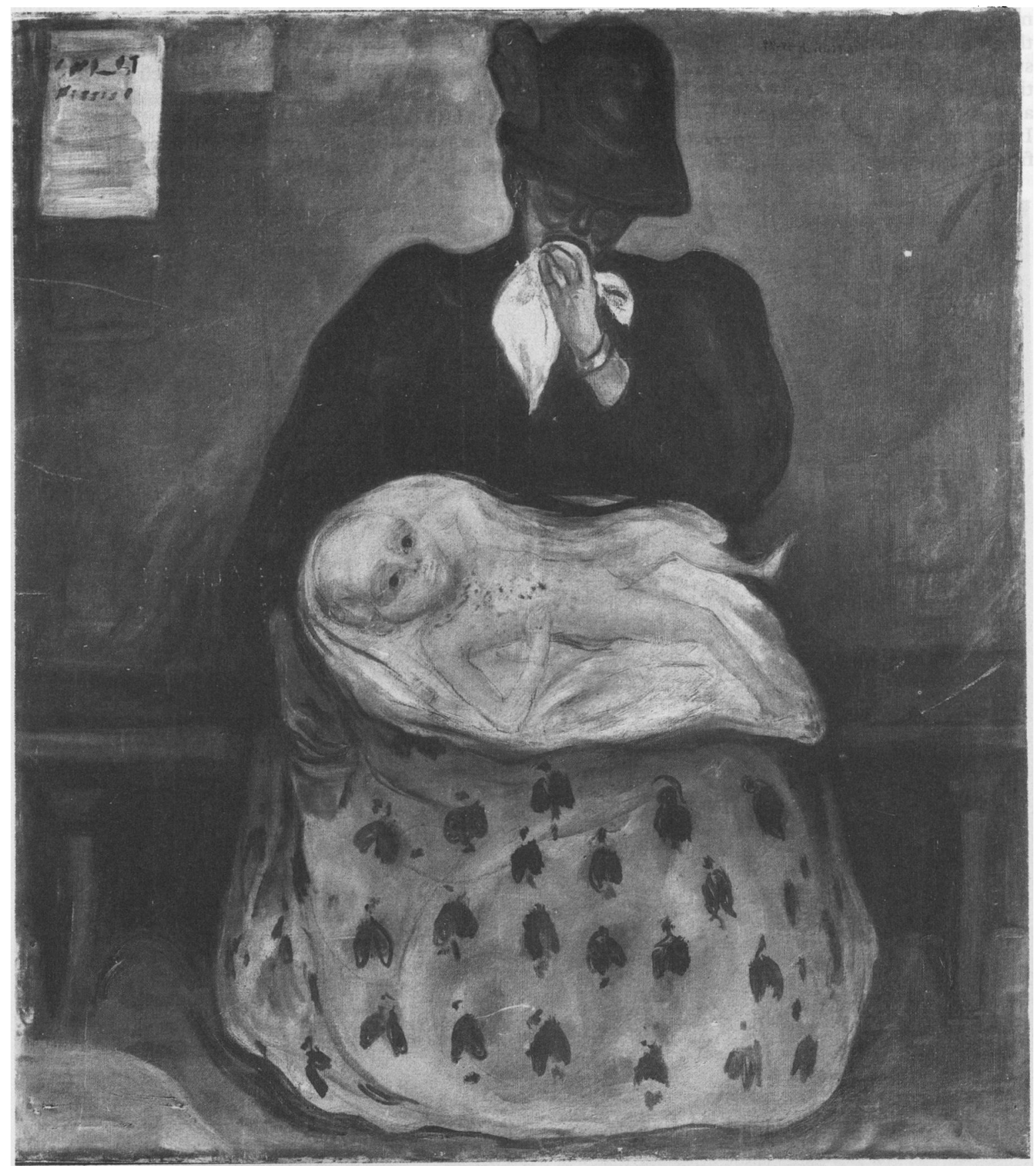

Fig 60 Eduard Munch. The Inheritance. Oil on canvas. 1897. Courtesy Munch Museet, Oslo. 
sailor rolling a cigarette. On our left is a medical student holding a skull-a Spanish symbol of mortality. (In some of the original drawings the figure on the left is a self-portrait.) The normal rounded configuration of the prostitutes makes them appear much less aloof, indifferent, remote and judgemental than those in the final version. There is no disturbing stare or coquettish look. We are not frightened, titillated or invited. In the presence of this preliminary work we are more spectators or, at most, voyeurs. If we have any sense of apprehension it comes only from Picasso's title, The Wages of Sin. Clearly this sketch is an allegory of syphilis. He feared the disease rather than the women. ${ }^{515354}$

The early part of the 20th century showed dramatic advances in the diagnosis and treatment of syphilis. Its causative organism, the treponema pallidum, was discovered in 1905 and the Wassermann blood test for the disease in the following year. In 1910 Ehrlich and Hata's research produced its 606th arsenical compound, salvasan. It was to revolutionise therapy.

In 1913 a light-hearted French satirical periodical called L'assiette au beurre, with a fine sense of fun,

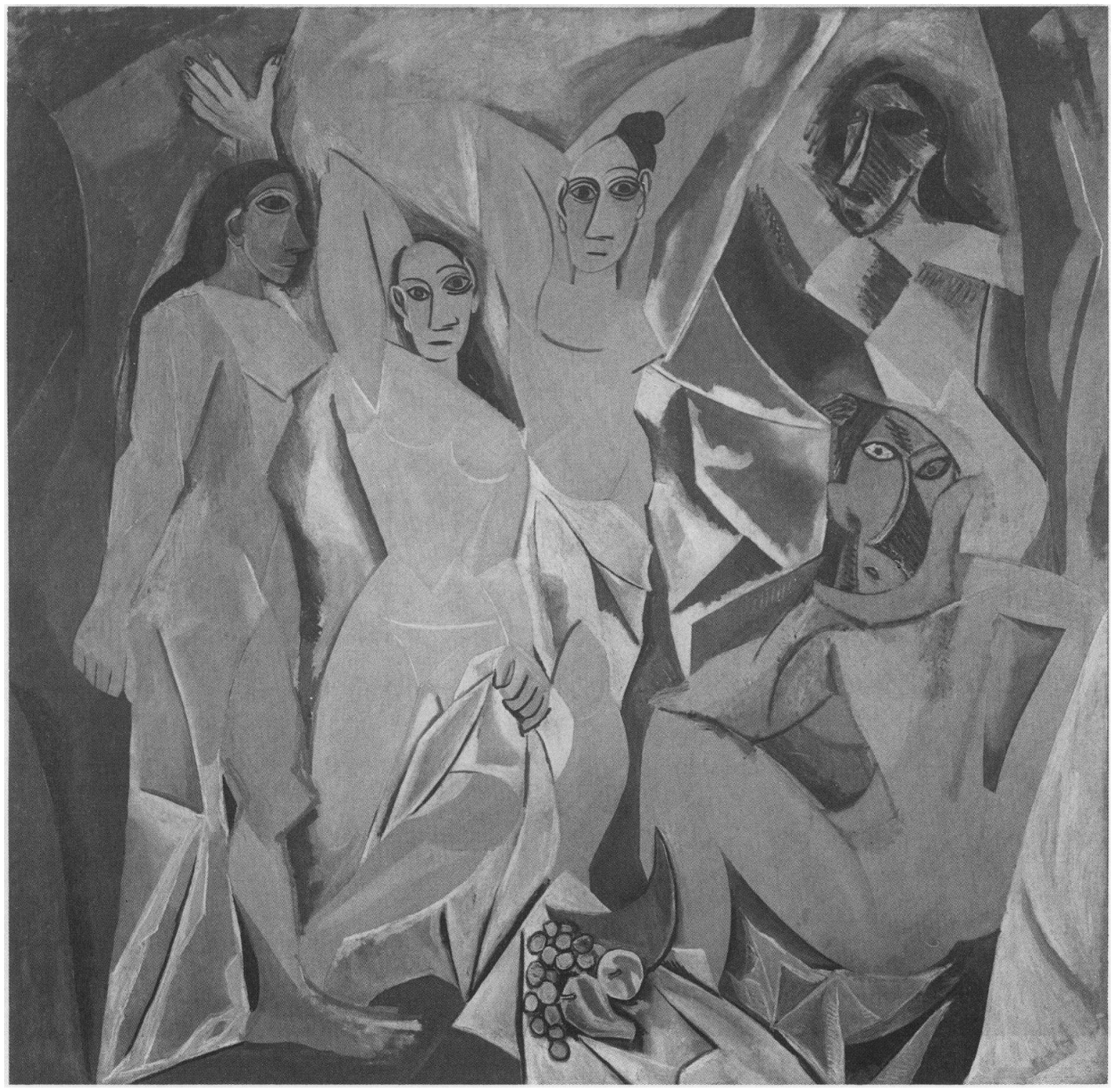

Fig 61 Picasso, Pablo. Les Demoiselles d'Avignon, 1907. Oil on canvas, $243.9 \times 233.7 \mathrm{~cm}$. Courtesy of The Collection, The Museum of Modern Art, New York. 


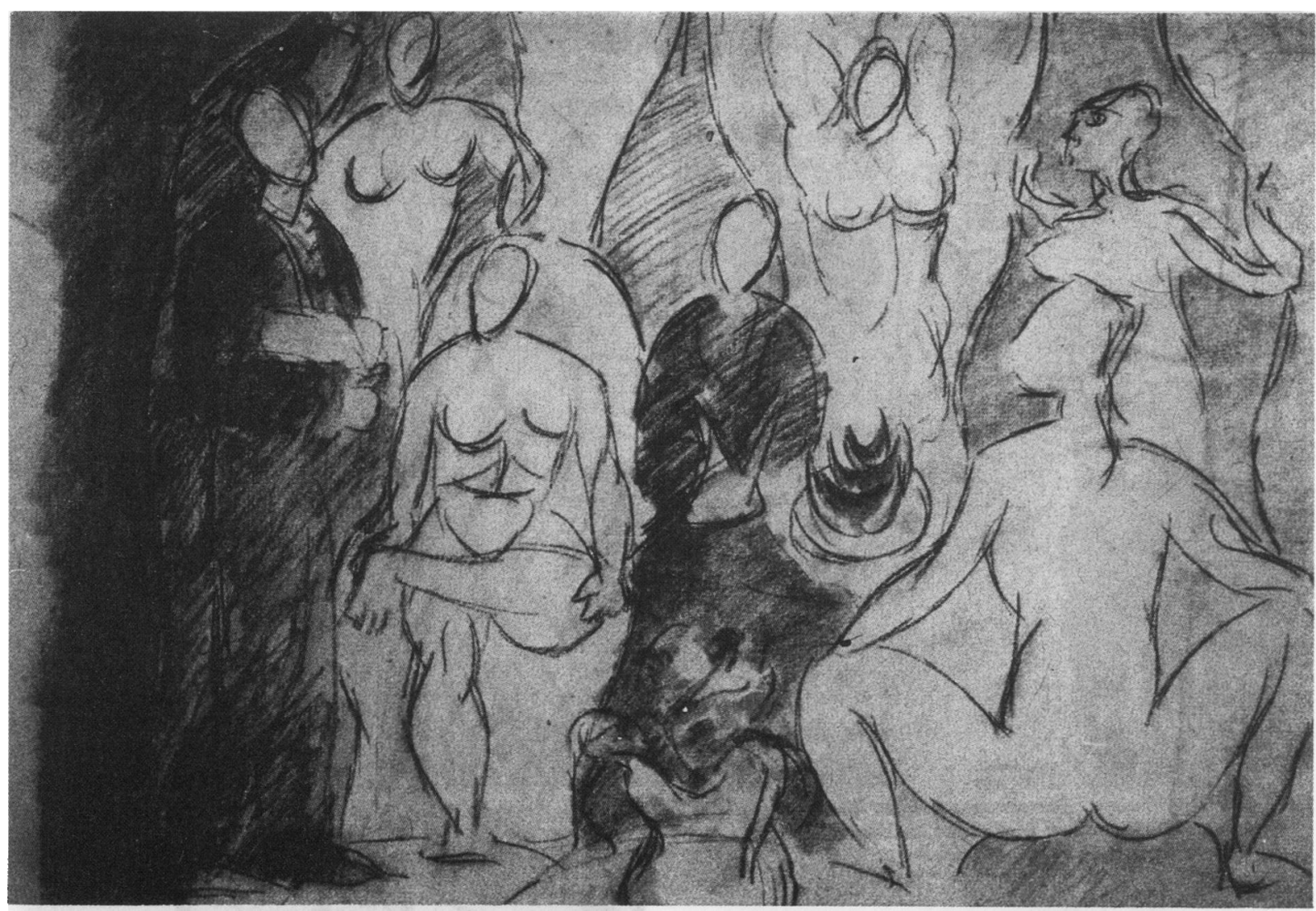

Fig 62 Pablo Picasso. The Wages of Sin. Study for Les Demoiselles d'Avignon. Courtesy Offentliche Kunstsammlung, Kupferstich Kabinett, Basel.

devoted its 606 th edition entirely to a collection of cartoons concerning syphilis. ${ }^{55}$ For the first time since the 18th century people laughed at the disease, not with bravado out of fear, but from hope born of understanding. The 20th century cartoonists, in contrast to their predecessors, used humour and laughter to cathartic effect. The media had launched the new era of public education by entertainment.

The first example from $L$ 'assiette au beurre (fig 63) mocks the public view that treponemes are everywhere. It was a pertinent comment since screening of Parisians with the new blood test had found $10 \%$ to be positive. Thus one small boy finds it necessary to reassure his inquisitive friend that the newly discovered organism is not the cause of another common consequence of sex, pregnancy.

$A$ victim of science (fig 64) shows that salvasan was not welcomed by everybody. The pharmacist is asked by his friend "How's business?", to which the dejected pharmacist replies, "Let's not talk about it; 606 has killed the sale of condoms". Little wonder that German students of the time were lustily singing in their beer halls ${ }^{56}$ :
"Even if you have pox for sure, Sweet wench, I'm yours ready for tricks Since it is easy now to cure With Ehrlich and Hata's six-o-six."

Figure 65 shows a familiar out-patient scene. An attentive physician is seated in his clinic at the St Louis Hospital, Paris. His serious, contemplative countenance leaves us in no doubt that the concern displayed by his worn-out Romeo patient is well directed. This is clearly no simple case of gonorrhoea. That it is the more serious syphilis finds some confirmation in the patient's state of déshabille.

The last of the examples from $L$ 'assiette au beurre was first published in 1905 (fig 66). It demonstrates how early and how long and determinedly our French colleagues have pursued public education. More than three-quarters of a century ago they were directing their efforts at what they recognised as a target group. The drawing is called Education for Ladies. The posters on the pissoir advertise doctors offering cures for venereal diseases. Such endeavours in such Parisian places were publicly acceptable. They demonstrate the pragmatism of Gallic logic and 


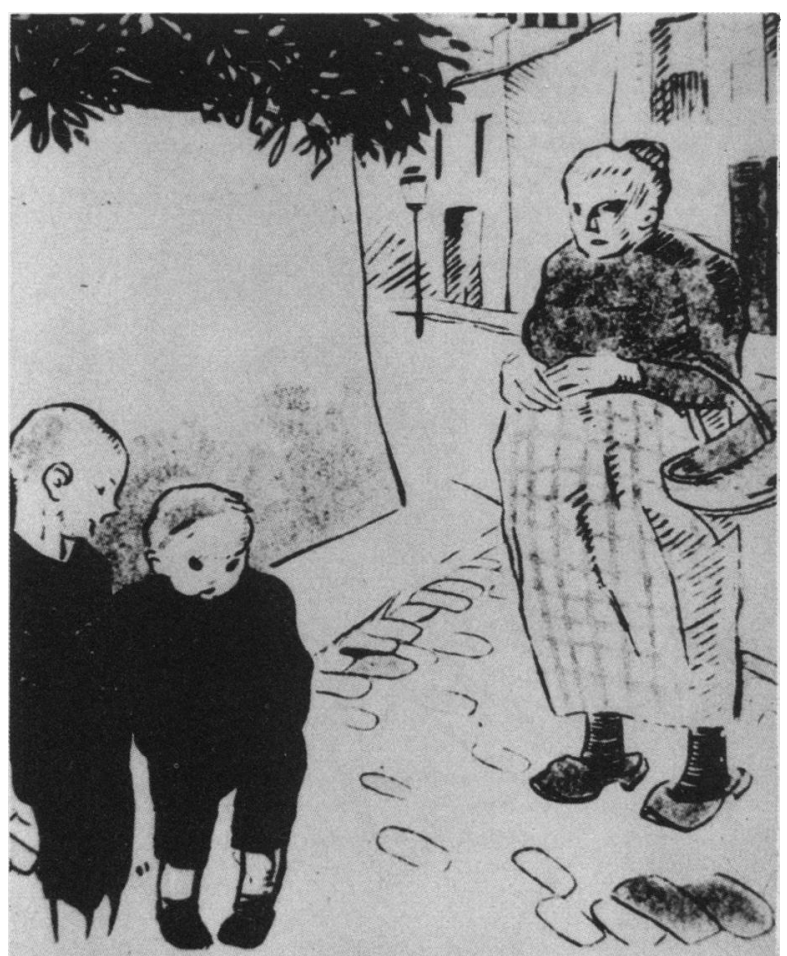

Fig 63 Anonymous. Spirocheata pallida is not the cause of pregnancy. Caricature in L'Assiette au Beurre, 1913. Courtesy of Springer-Verlag, Heidelberg.

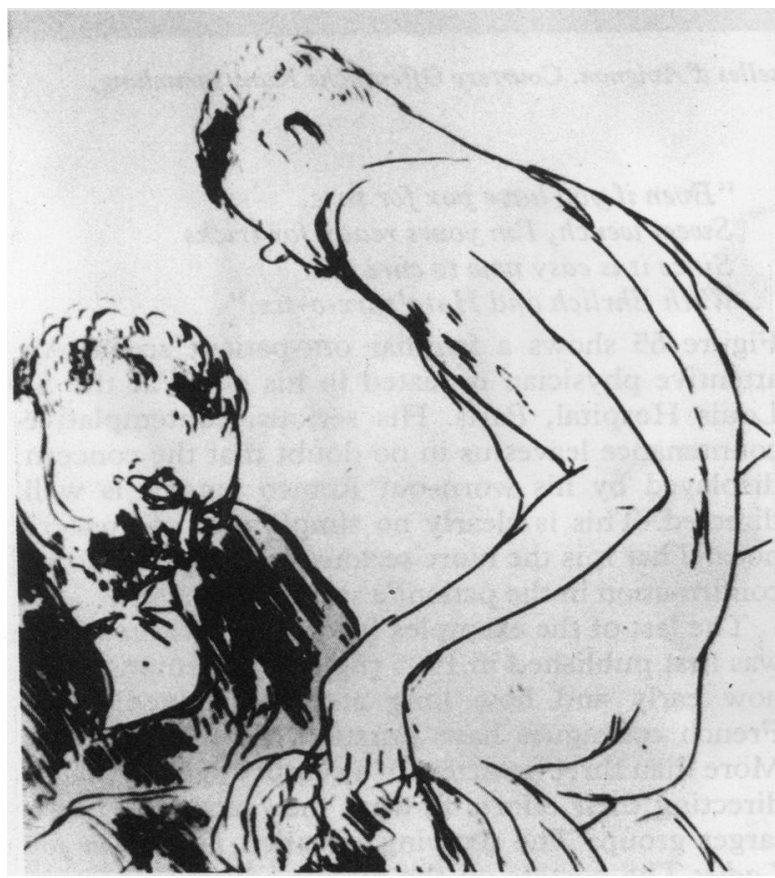

Fig 65 A. Dunoyer de Segonza. Consultation at the St. Louis Hospital, Paris. Caricature in L'Assiette au Beurre, 1913. Courtesy of Springer-Verlag, Heidelberg and Design and Artists Copyright Society Ltd., London.

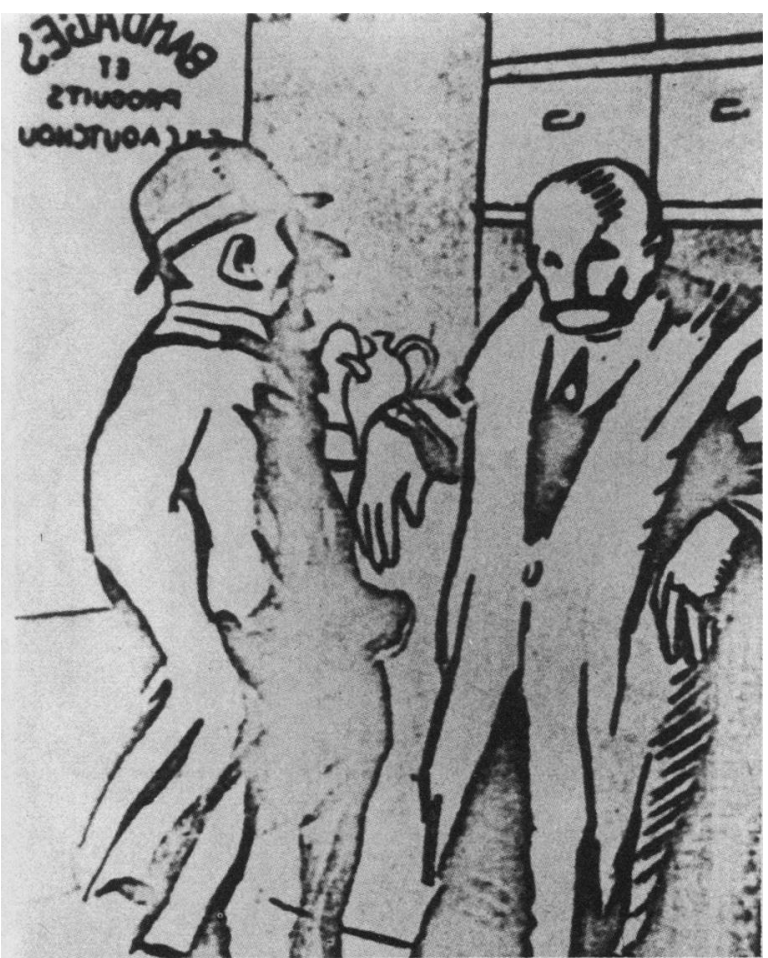

Fig 64 Anonymous. A Victim of Science. Caricature in L'Assiette au Beurre, 1913. Courtesy of Springer-Verlag, Heidelberg.

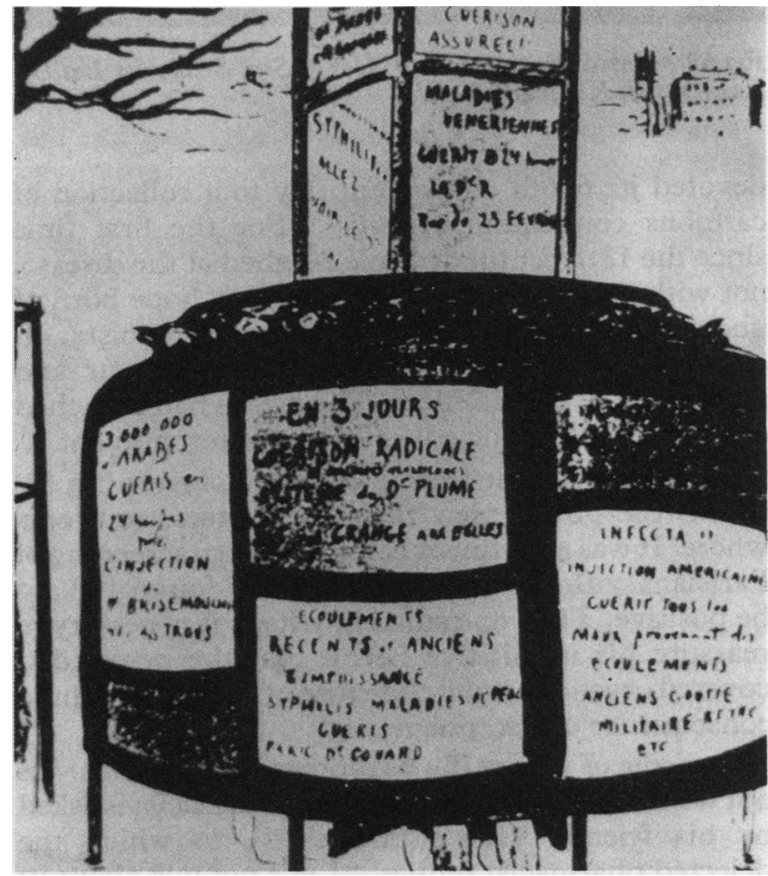

Fig 66 Anonymous. A Practical means of educating ladies. Caricature in L'Assiette au Beurre, 1913. Courtesy of Springer-Verlag, Heidelberg. 


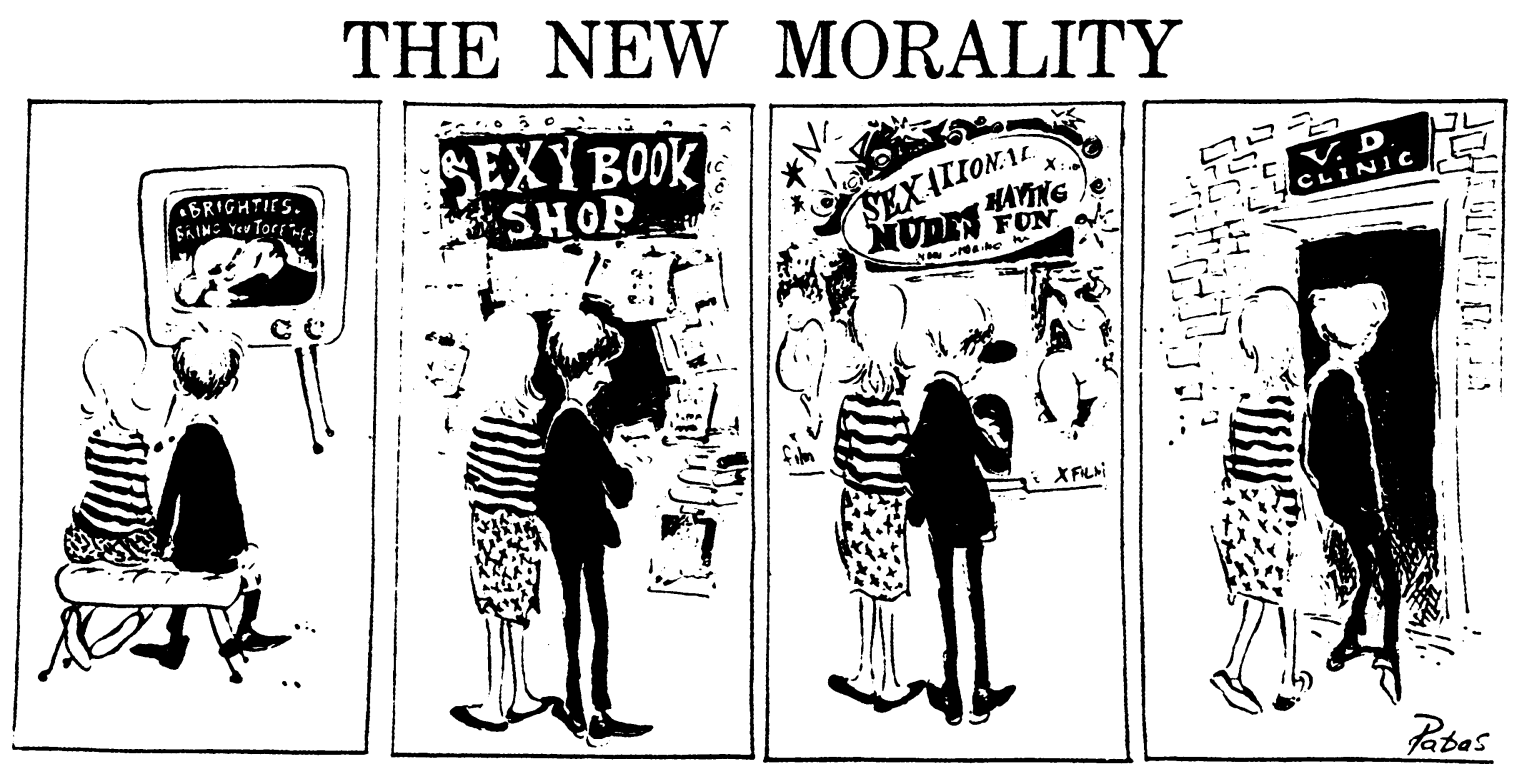

Fig 67 Papas. The New Morality. Sunday Times. 8 March, 1964. Courtesy Times Newspapers Ltd. London.

match the more relaxed attitudes prevailing in France at the time. They contrast strikingly with those pertaining in Britain.

The caricatures of our own time are in all respects the mildest ever. Figure 67 is a Papas caricature published in the Sunday Times of 8 March 1964. Its blandness typifies the cult of non-judgemental comment current in the 1960s.

Penultimately in this collection we have, like the first item, an artist's translation of an idea into threedimensional art. Not long after the death of John F Kennedy several sculptors put forward, around 1968-69, ideas for a memorial to him. Figures 68 and 69 suggested a monumental stone sculpture - a form of artistic expression, alas, currently finding little favour. John Kennedy's absorbing interests and hopes are represented. Firstly, Medicare in the group of senior citizens, secondly the colour problem and thirdly the problems of the underdeveloped countries. This last is represented by a mother with her children. Of the several diagnoses on offer in the total piece, note especially the thickened bowed tibia of the young mother. This imaginative and skilfully constructed creation is called a maquette and is of vinyl gel plaster. It is the work of the sculpturess, Dr Mary Catterall.

Syphilis, in the Western World at least, is so much under control as to be no longer a public health or social problem. This has pertained for nearly a quarter of a century. Why then conclude with a 1972 production? (fig 70). And why Maina-Miriam Munsky's Colposcopy? Is the colposcope not a modern instrument to deal with some of the new generation of

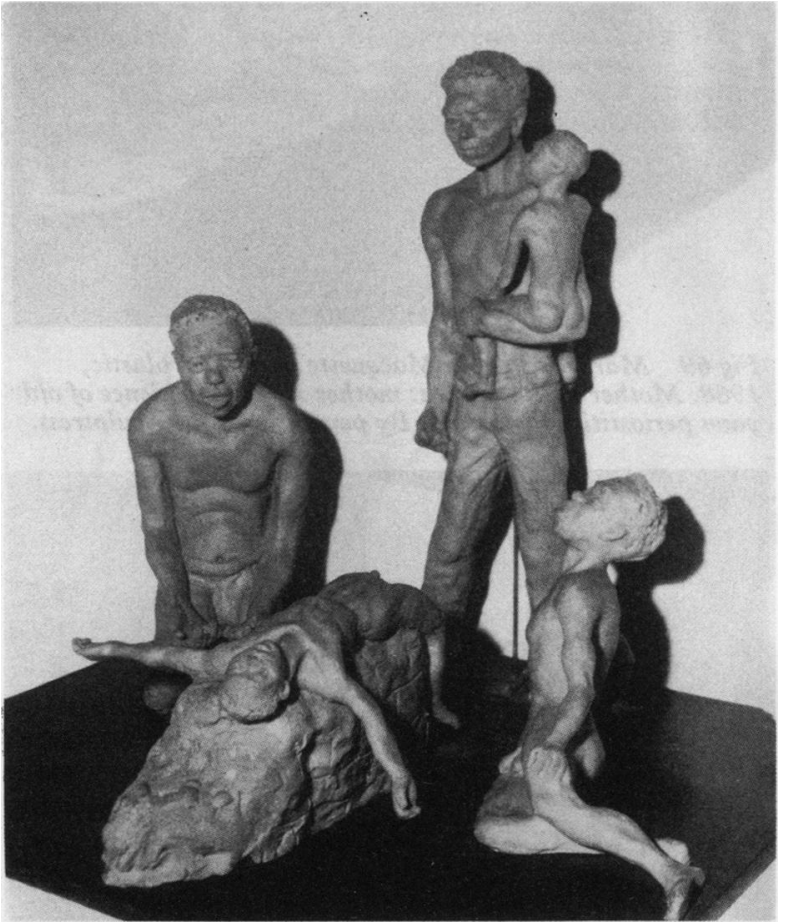

Fig 68 Mary Catterall. Macquette in vinagel plastic, 1968. It shows one of John F. Kennedy's interests, the underprivileged of the third world. By permission of the sculptress. 


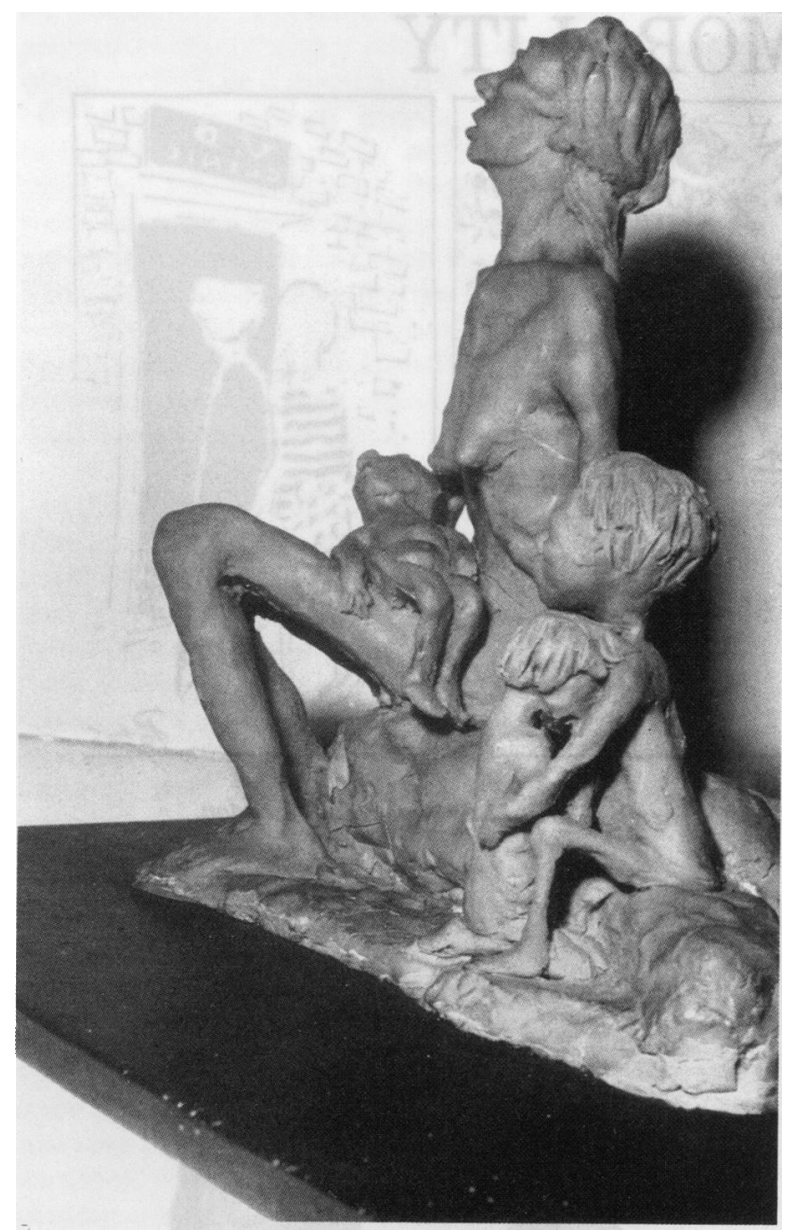

Fig 69 Mary Catterall. Macquette in vinagel plastic, 1968. Mother with children: mother showing evidence of old yaws periostitis of left tibia. By permission of the sculptress.

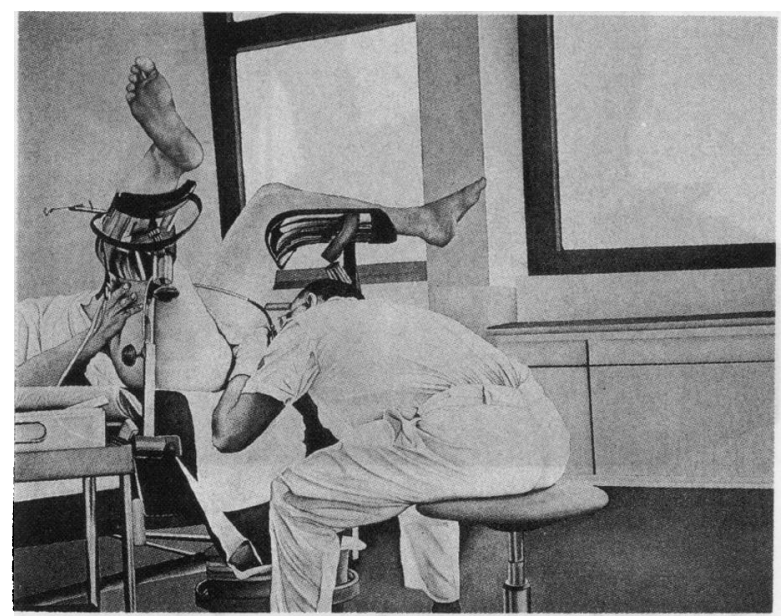

Fig 70 Maina-Miriam Munsky. Colposcopy. Oil on canvas. $150 \times 180 \mathrm{~cm} .1972$. Courtesy of The Nicholas Treadwell Gallery, Womenswold, Nr. Canterbury. sexually transmitted diseases-genital herpes and warts, chlamydial infection and the increasingly ubiquitous and life-threatening carcinoma of the cervix? Well, yes. But all this could change dramatically if non-treponicidal drugs were to be introduced and widely applied as treatment for gonococcal and/or chlamydial infections. Then, as only rarely today, genitourinary physicians and medically orientated gynaecologists would again be confronted with the fact that some $25 \%$ of primary syphilitic sores in women occur on or in the cervix..$^{57}$

But perhaps I too readily anticipate tomorrow's history.

In conclusion, artists have throughout the centuries recorded men's fears, foibles and follies in relation to syphilis. By holding up a mirror, artists have offered an opportunity to men and women to reflect on their attitudes and behaviour. Changes have been slow, intermittent, marginal, unsustained and reversible.

The future, it seems, offers nothing more certain.

\section{Acknowledgements}

My prime debt is to the late Erwin Panofsky, art historian, whose Homage to Fracastorius first gave me an interest in art. I am greatly indebted also to colleagues for suggestions and to members of the Department of Medical Illustration, Royal Hallamshire Hospital, Sheffield for technical advice and skill with reproductions. Staffs at museums, galleries and libraries have been unfailingly helpful. Special thanks are due to Anne Goodchild, Graves Art Gallery, Sheffield, Alexander Kader, Witt Library, London and William Schupbach, Wellcome Institute for History of Medicine, London.

Address for reprints: 9 Cortworth Rd, Sheffield S11 9LN, UK

43 Alibert JL. Descriptions des maladies de lay peau. Paris: 1836. (pl 41 shows fig 48 as "syphilide pustuleuse en grappe").

44 Catalogue: Medicine through the Artist's Eye for Wellcome Institute Exhibition, The Science Museum, London: 1978.

45 Blanchard R. Maladies vénériènes dans l'art. Deux éstampes sur la syphilis. Aesculape, 1940-49;30:142-3.

46 Petrie G. A Singular Iniquity. London: MacMillan, 1971.

47 Ward F. Munch and his Contemporaries. Scanorama, Sweden, Scandinavian Air Lines, 1974;3:20-4.

48 Fermigier A. Toulouse-Lautrec. Trans by Paul Stevenson. London: Pall Mall Press, 1969.

49 Durel P. Un portrait du syphilographe Alfred Fournier dans un tableau de Toulouse-Lautrec. Hist. des Sciences Medicales, 1974;8:721-6.

50 Richter H. Dada: Art and Anti-Art. London: Thames and Hudson, 1965:101.

51 Hughes R. The Shock of the New. London: British Broadcasting Corporation, 1980;21-4:73-7.

52 Dunlop I. Edvard Munch. London: Thames and Hudson, 1977.

53 Barr AH. Picasso: Fifty Years of His Art. London: Secker and Warburg, 1975.

54 Berger J. Success and Failure of Picasso. Harmondsworth, Penguin Books, 1964

55 Vogt H. Medizinische Karikaturen von 1800 bis zur Gegenwart. Munchen, Lehman, First Ed. 1962.

56 Oller L. (personal communication) 1969.

57 Davies TA. Primary Syphilis in the Female. London, Oxford University Press, 1931, p 43.

Accepted for publication: 10 October 1989 